\title{
Framework for the Future: Annual Report 2016
}

Population Council

Follow this and additional works at: https://knowledgecommons.popcouncil.org/ series_newsletters_annualreports How does access to this work benefit you? Let us know!

\section{Recommended Citation}

"Framework for the Future: Annual Report 2016." New York: Population Council, 2017. 


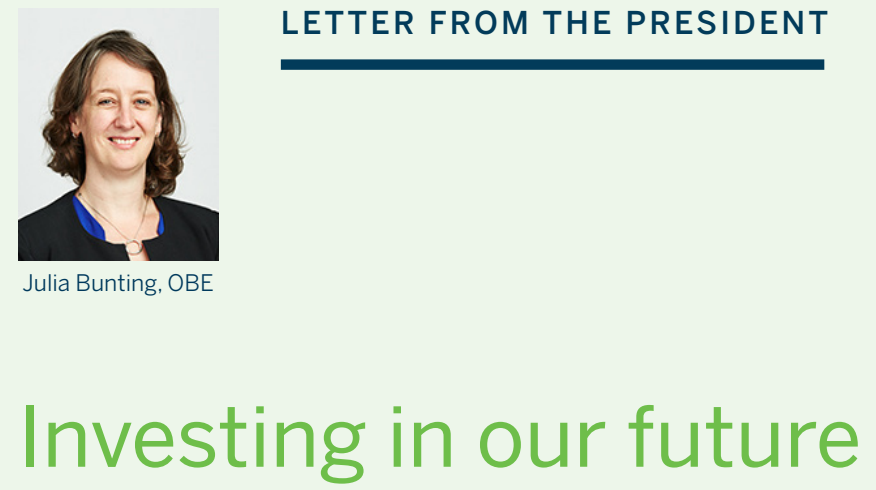

For many of us, 2016 felt like a tumultuous year as we witnessed contentious elections, escalating conflicts, and the warmest year on record globally. While these experiences made many of us want to retreat into the safety of our family and friends, they also offered a strong reminder that our work is far from done.

Throughout the last 65 years, the Council has advanced rights, enhanced equity, and improved lives. We have done this by delivering rigorous, unbiased evidence that aids diverse governments, decisionmakers, and agencies to improve programs and ensure policies are having the intended impact. Despite sometimes differing views-or perhaps particularly when views differ-we have found that evidence can bring clarity to a confusing and divided world.

A climate of fear can contribute to increasing isolation. Despite our progress on girls' rights, Population Council research has shown that when families feel that neighborhoods aren't safe, girls see their worlds shrink and opportunities contract. They may be pulled from school, socially isolated, forced into labor or marriage, and are more at risk of early pregnancy and HIV infection.

The good news is that when we design programs based on rigorous evidence about the realities of girls' lives, we make a real impact. This year, our groundbreaking BALIKA project reduced the likelihood of child marriage by as much as 31 percent in communities in rural Bangladesh. By providing "safe spaces" that offered education and training opportunities, BALIKA helped enhance the lives and opportunities of adolescent girls and proved a model that is now being scaled up.

These impressive results tell me that when we develop innovative programs backed by rigorous evidence, we have an opportunity to create real and lasting change. And this is what the Population Council does best. 
Despite the tumultuous events around us, 2016 stimulated big ideas at the Council. We set out to consider how evidence can solve challenges for our global future, from improving the health and well-being of the world's youngest and most vulnerable populations, to advancing reproductive health and rights. We asked ourselves: how do we define impact, and how will we get there?

By the end of the year, we had created a Strategic Priorities Framework that sets our vision for the future. Over the coming years, it will direct our talent and resources toward critical health and development issues where we believe our research can make the biggest contribution. In the short term, we're investing in analysis on specific, critical issues that are not well enough understood. For instance, the world has made great progress on getting more girls into school, but made far less progress on the quality of education they get once they're there. We are exploring how we can best reduce school dropout and make sure all girls achieve the learning outcomes that will set them up for a successful future.

It's important to me that our commitment to worldclass research is underpinned by a commitment to strong organizational health. It's our incredible people around the world who generate our ideas, evidence, and impact. So we're doing more to ensure their work can be successful, and in doing so, give our donors the very best value for money. Through convening research teams and operations experts, our Strategic Priorities Framework is a tool to empower our people to drive their ideas forward and continue to achieve the kind of impact for which the Population Council is renowned.

As a global community, we face major challenges ahead, and fewer resources to meet them. Too much is at stake to waste money on programs that sound good but haven't been shown to be effective. I feel immensely privileged to lead an organization that is generating the ideas we need to tackle these challenges, and applying the intellectual rigor we need to test them.

At a time when progress seems fragile, our strategy is to invest in evidence to show what is effective, why, and when. That way the ideas we have today will continue to change the way the world thinks for years to come.

\section{GOALS}

Improve the wellbeing of vulnerable populations, especially girls and women

Advance sexual and reproductive health and rights

Accelerate positive demographic trends

Research, develop, and bring to market sexual and reproductive health technologies

Promote evidencebased approaches for the solution of development challenges

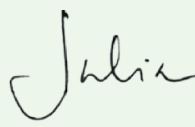

Julia Bunting, OBE

President 


\section{Strategic Priorities Framework}

\section{OBJECTIVES}

Empower girls to lead productive lives through improved access to quality education and health services

Expand and improve access, choice, equity, and quality in contraceptive and safe abortion services

Increase understand ing of demographic trends and their consequences for human welfare and the environment, particularly in subSaharan Africa

\section{Develop new} contraceptives, products to prevent HIV/STI transmission, and other public health products, and test for effectiveness, safety, and acceptability

Ensure that research is used to inform development policies, programs, and investments in the public, private, and nongovernmental sectors
Reduce the traditional practices such as child, early, and forced marriage and female genital mutilation/cutting

Reduce STI and HIV risk and improve HIV care and treatment programs prevalence of harmful
Reduce

sexual and

gender-based

violence
Increase knowledge and understanding of the biology of HIV/STI

transmission, regulation of fertility, and sexual and reproductive health

Publish the best research on population, health, and development
Address the social and health needs of key population groups and improve quality of life for people living with HIV

\section{PRIORITIES}

- Enhance the evidence base for reducing school dropout and improving learning outcomes for girls

- Demonstrate how addressing stigma and gender inequities improves HIV and AIDS program outcomes

Reduce maternal and newborn morbidity and mortality

- Develop and use evidence to enable programs to reduce

social and economic barriers to obtaining quality maternal health services

- Develop evidence on how to strengthen the resilience of vulnerable populations to adapt to environmental shocks and stressors, including those related to the effects of climate change

- Undertake research and provide technical assistance to prepare markets for introduction of the PVR, NES/EE CVR, and Multipurpose Prevention Technologies developed by the Council and others

- Identify and advance a lead candidate from the Center for Biomedical Research's current product portfolio to the next phase of development

- Generate and promote policy-relevant evidence to support programs for girls at scale

\section{ORGANIZATIONAL HEALTH GOALS}

The Council is an employer of choice, staffed by top talent
The Council's structures and systems allow us to collaborate and coordinate to maximize delivery of our mission
The Council has sound financial health, enabling it to carry out its mission 
The Population Council conducts rigorous biomedical, public health, and social science research to improve lives around the world. Our work advances reproductive health, allowing couples to plan their families and chart their futures. We help people avoid HIV infection and access life-saving HIV services. And we empower girls to protect themselves and have a say in their own lives. Ideas. Evidence. Impact. It's our model for change.

\section{What works to delay child marriage?}

IDEAS: BREAKING THE

CYCLE OF CHILD MARRIAGE

Despite having made significant progress on many gender and reproductive health indicators, two out of three girls in Bangladesh are married before the legal age of 18 . When girls are married early, they are more likely to drop out of school, be unemployed, and experience violence and harassment. Even as adults they tend to be more socially isolated, have fewer resources, and be less educated. A delayed marriage greatly improves a girl's chances for a healthy and productive life.

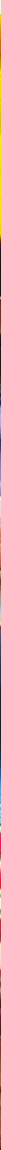




\section{EVIDENCE: USING RIGOROUS RESEARCH FOR SOCIAL CHANGE}

The Council established a rigorous study to evaluate effective approaches to delay child marriage.

The "Bangladeshi Association for Life Skills, Income, and Knowledge for Adolescents" (BALIKA) project, supported by the Embassy of the Kingdom of the Netherlands, evaluated whether three skills-building approaches to empower girls could effectively delay the age at marriage among girls aged 12-18.

Participating communities were assigned to three different intervention groups in which girls received either:

- Education support and tutoring;

- Training on life skills and gender rights awareness; or

- Livelihoods training to support entrepreneurship or useful skills, such as mobile phone servicing.

Another 24 communities served as the control group where no intervention occurred.

\section{IMPACT: SCALING UP FOR THE FUTURE}

Results showed that girls in BALIKA communities were nearly one-third (31\%) less likely to be married as children than girls living in communities not reached by the BALIKA project. The findings demonstrated that a holistic approach to building girls' skills and knowledge, elevating their visibility and status in their families and communities, and ensuring their safety could reduce the chances that they marry too soon.

Today the BALIKA project continues in many of the intervention communities thanks to efforts by the teachers, mentors, and community leaders, and the government is scaling up the approach in more communities nationwide.

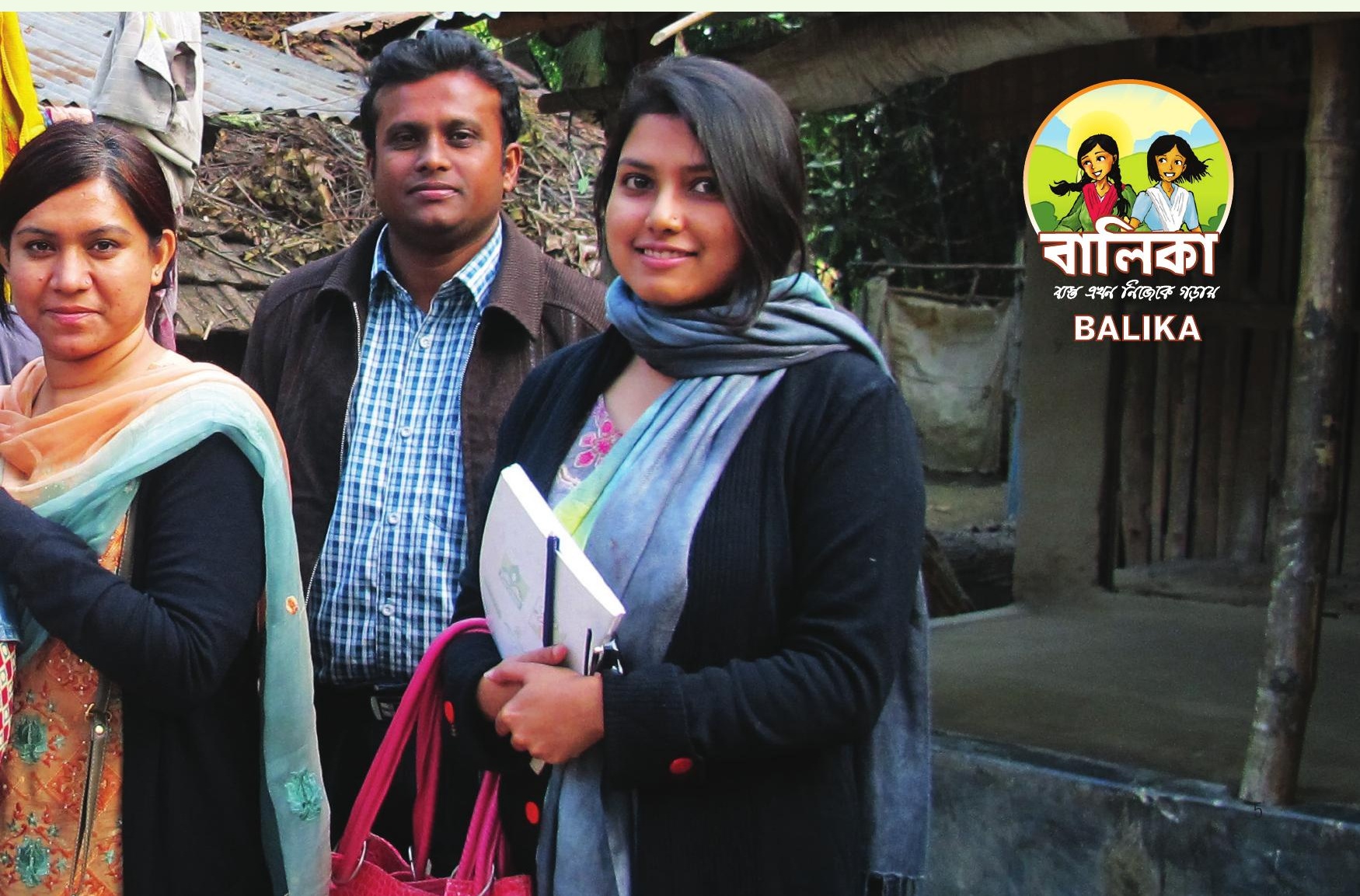




\section{Informing policies and programs}
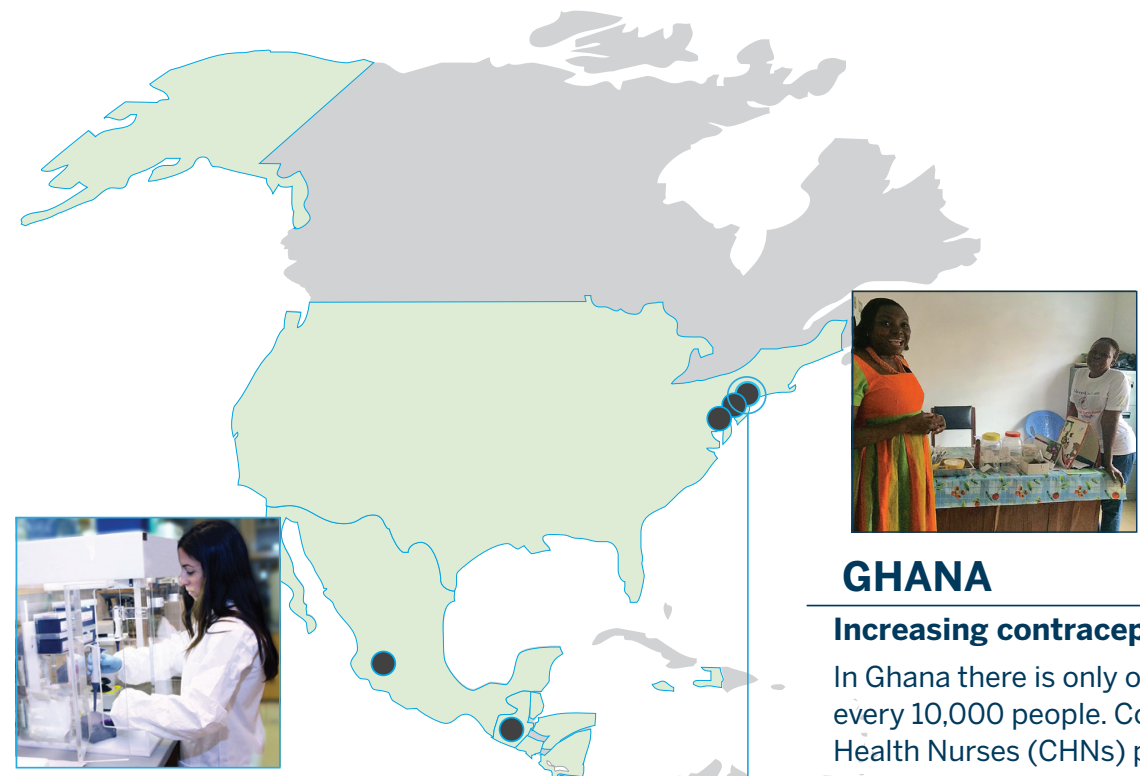

GHANA

\section{UNITED STATES}

Advancing multipurpose prevention technologies

The Council advanced the promising PC-1005 gel with publication of the first in-human trial results showing the broad spectrum microbicide is well-tolerated and has high acceptability. PC-1005 gel, also known as $M Z C$, is designed to be used both vaginally and rectally to protect women and men against HIV, herpes simplex virus, and human papillomavirus. It contains the highly potent antiretroviral MIV-150, along with zinc acetate dihydrate and carrageenan.

Countries where we work

Country offices
Increasing contraceptive choice

In Ghana there is only one doctor for every 10,000 people. Community Health Nurses (CHNs) play a critical role in providing roughly $60 \%$ of Ghana's contraceptive services. Until recently they were unable to offer contraceptive implants-an important option for women in hard-to-reach areas. In 2013 the Council and Ghana Health Service piloted a project to train nurses in implant insertion and removal. The pilot's positive results prompted a national policy review, and now $\mathrm{CHNs}$ can provide the implant services directly to women, dramatically expanding contraceptive access and choice.

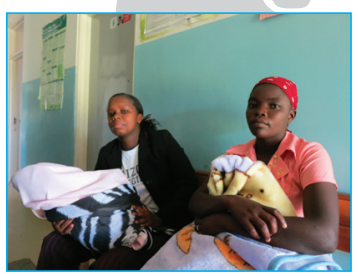

KENYA

Sending teen mothers back to school

Two out of five 19-year-old Kenyan girls are pregnant or have given birth. Through STEP UP, a DFID-supported project to generate policy-relevant research on sexual and reproductive health, the Council identified the impact of unplanned pregnancy on girls' education, including finding that pregnancy was cited as the main reason (66\% of respondents) that girls ages 13-19 drop out of school in Homa Bay, Kenya. The effort is paying off: a new parliamentary bill introduced in 2016 prohibits schools from requiring pregnancy tests or expelling teen mothers and requires schools to provide a welcoming setting. 


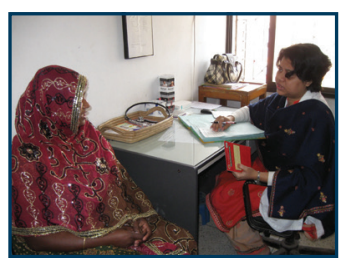

\section{BANGLADESH}

\section{Reducing stigma and discrimination}

Council research shows that combating stigma and discrimination is essential for reducing fear related to HIV testing and treatment. Through the Link Up project funded by the Dutch Ministry of Foreign Affairs, the Council found that tailored anti-stigma training substantially improved health provider attitudes, such as reducing the perception that people living with HIV should be ashamed (from $35 \%$ to $16 \%$ ). Young people's approval of services also improved after the training (from 64\% to 98\%), showing it is possible to provide respectful services to marginalized groups.

\section{EGYPT}

\section{Protecting women's and girls' rights}

Through the nationally representative 2014 Survey of Young People in Egypt, Council researchers found an alarming result: a growing proportion of girls and women reported undergoing female genital mutilation/cutting (FGM/C) by medical professionals, despite FGM/C offering no health benefits. To help address the issue, the Council convened policymakers to share and translate the findings into action. As a result, an amended law strengthened penalties against physicians convicted of the practice. A nationwide "Doctors against FGM/C" campaign was also launched.

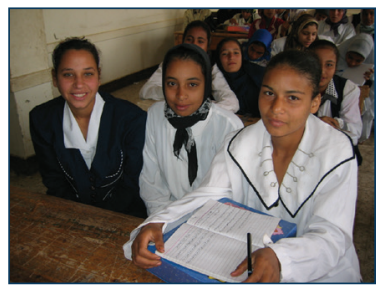


In order to have impact, evidence must reach and be used by decision-makers. Sharing our findings with peers, policymakers, and the public is essential for creating lasting change.

\section{TOOLS AND RESOURCES}

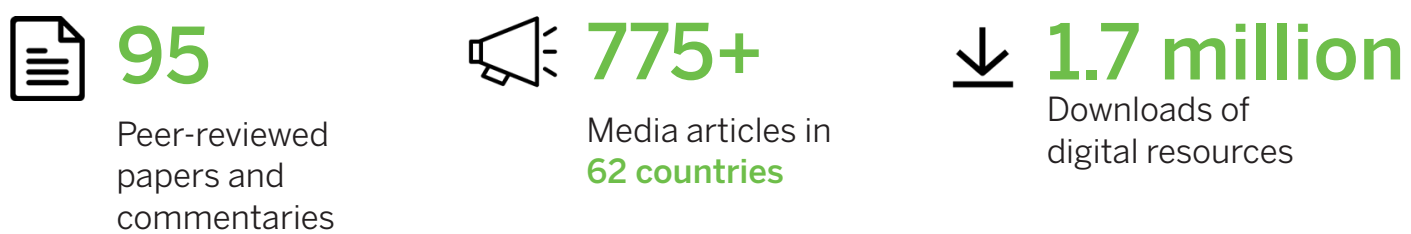

\section{GLOBAL RECOGNITION}

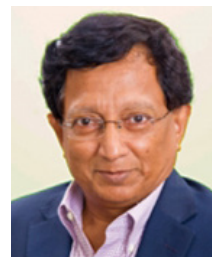

Ubaidur Rob, Country Director, Bangladesh, was honored by the Obstetrical and Gynecological Society of Bangladesh for contributions toward reducing pre-eclampsia

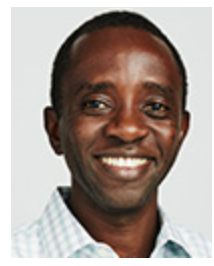

Chernor Bah, Poverty, Gender, and Youth program, received the Together for Girls "16 Heroes Award" for dedication to ending domestic violence

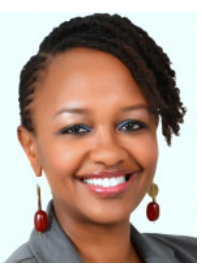

Eunice Muthengi, Poverty, Gender, and Youth program, won the International Center for Research on Women's 2016 Paula Kantor Award for Excellence in Field Research

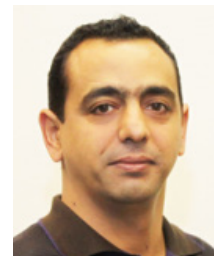

Samir Souidi, Information Technology, received the InsideNGO 2016 Excellence Award in Information Technology

\section{$\checkmark$ WITHOUT THE TOOLS FROM THE POPULATION COUNCIL, IT WOULD HAVE BEEN MUCH MORE DIFFICULT, IF NOT IMPOSSIBLE FOR US TO GATHER SOME OF THE VITAL INFORMATION WE COLLECTED."}




\section{CITED AND DISCUSSED}

\section{nature}

"Within a decade, women everywhere should have access to quality contraceptive services... Family planning must be reclassified as a development intervention (as well as being a health and human-rights intervention) to give it the high national and global priority it deserves."

-John Bongaarts Vice President and Distinguished Scholar

\section{THE LANCET}

"Most health experts say there is no mystery surrounding what is needed to tackle maternal deaths, many of which are preventable. 'We know what can be done,' said Charlotte Warren, who leads maternal health research at the Population Council... 'Women are not getting access to basic services in many countries."'

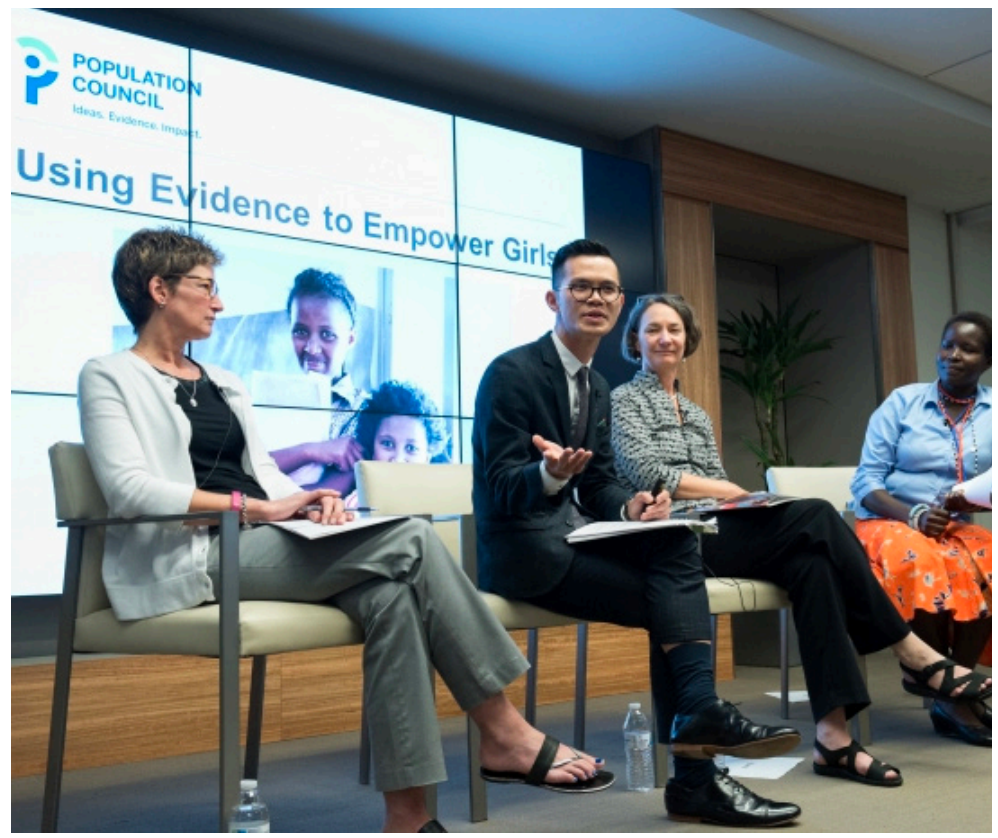

\section{JAIDS}

"The capacity of PC-1005 to block HPV is critical given that multiple strains of HPVincluding low risk types that are not included in any of the currently available vaccineshave been shown to double HIV risk in certain settings."

- Barbara Friedland

Associate

HIV and AIDS program

\section{devex}

“There is a 'staggering' gap in the research and literature focused on what works to improve the health and well-being of adolescent girls, according to Ngo. Between 1990 and 2014, only 77 research articles were written on the topic, he said, and of those only 29 percent could be considered "high-quality research."

-Thoai Ngo

Program Director

Poverty, Gender, and Youth program

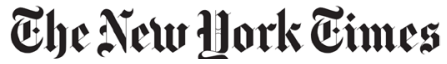

"The H.I.V. epidemic has become progressively younger while remaining persistently female. In the most affected regions, young women are two to four times more likely to become infected than men... We can genuinely make AIDS a crisis of the past only by using evidence-based solutions designed with girls at the center..."

\section{theguardian}

"If we want to effectively reduce child marriage in Bangladesh, we must employ new approaches that empower girls, and engage their families and their communities so girls are seen as an asset, not a liability."

- Sajeda Amin

Senior Associate Poverty, Gender, and Youth program 
The charts on this page provide details on the Council's sources of support and use of funds. The Council's program-spending ratio, a key financial indicator, was 84 percent for fiscal 2016. For every dollar spent, 84 cents goes directly to research and program activities, demonstrating our prudent management and commitment to our mission.

We closely monitor the Council's financial status and remain committed to the fiscal discipline necessary to maintain our record of accomplishments. Readers interested in learning more about the Council's finances can consult http://popcouncil.org/who/ financials.asp

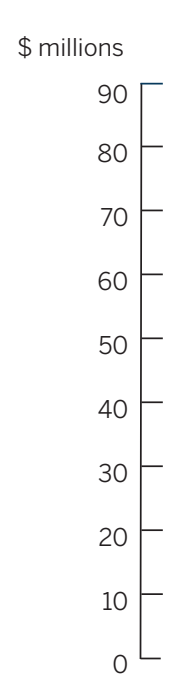

\section{SOURCES OF SUPPORT}

TOTAL \$84.5 MILLION

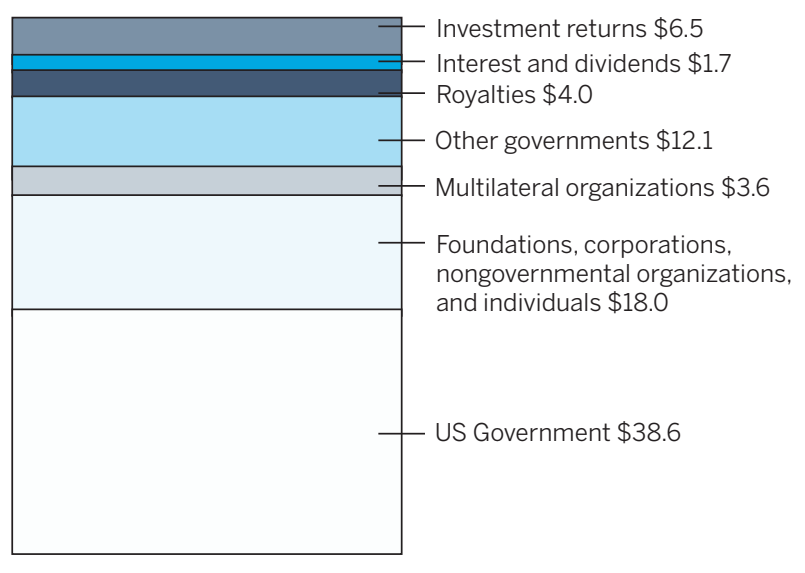

USES OF FUNDS

TOTAL \$85.2 MILLION

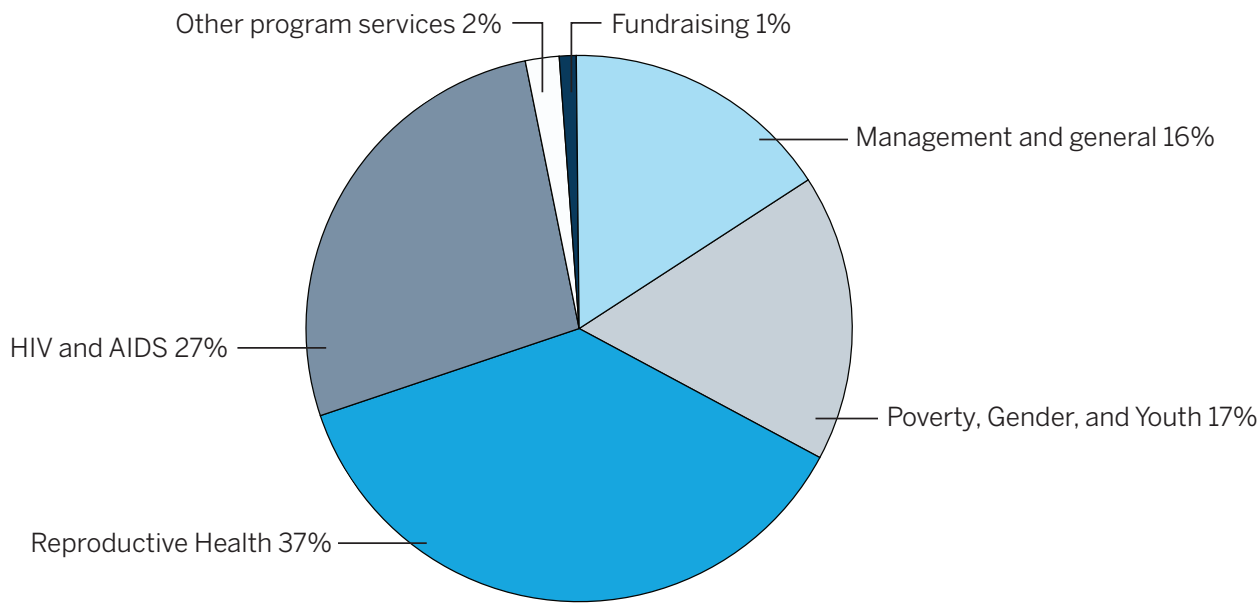


STATEMENT OF ACTIVITIES (For the year ended December 31, 2016)

\begin{tabular}{|c|c|c|c|c|c|c|}
\hline & \multicolumn{3}{|c|}{ Unrestricted } & \multicolumn{2}{|c|}{ Restricted } & \multirow[b]{2}{*}{ Total } \\
\hline & $\begin{array}{r}\text { General } \\
\text { undesignated }\end{array}$ & $\begin{array}{r}\text { The John D. } \\
\text { Rockefeller 3rd } \\
\text { Memorial Fund } \\
\text { and others }\end{array}$ & Total & $\begin{array}{r}\text { Temporarily } \\
\text { restricted }\end{array}$ & $\begin{array}{r}\text { Permanently } \\
\text { restricted }\end{array}$ & \\
\hline \multicolumn{7}{|l|}{ OPERATING REVENUE } \\
\hline Grants and contributions & $\$ 72,019,181$ & 1,000 & $72,020,181$ & 297,864 & - & $72,318,045$ \\
\hline Royalties & $4,027,938$ & - & $4,027,938$ & - & - & $4,027,938$ \\
\hline $\begin{array}{l}\text { Interest and dividends (net of } \\
\$ 196,441 \text { investment fees) }\end{array}$ & 1,653 & $1,386,726$ & $1,388,379$ & 272,018 & - & $1,660,397$ \\
\hline $\begin{array}{l}\text { Net appreciation in fair value } \\
\text { of investments }\end{array}$ & $(27,253)$ & $5,506,833$ & $5,479,580$ & $1,027,499$ & - & $6,507,079$ \\
\hline Net assets released from restrictions & 683,143 & - & 683,143 & $(683,143)$ & - & - \\
\hline TOTAL OPERATING REVENUE & $76,704,662$ & $6,894,559$ & $83,599,221$ & 914,238 & - & $84,513,459$ \\
\hline \multicolumn{7}{|l|}{ OPERATING EXPENSES } \\
\hline \multicolumn{7}{|l|}{ Program services } \\
\hline HIV and AIDS & $23,075,388$ & - & $23,075,388$ & - & - & $23,075,388$ \\
\hline Poverty, Gender, and Youth & $14,697,377$ & - & $14,697,377$ & - & - & $14,697,377$ \\
\hline Reproductive Health & $28,305,429$ & $3,155,775$ & $31,461,204$ & - & - & $31,461,204$ \\
\hline Distinguished Colleagues & 102,367 & - & 102,367 & - & - & 102,367 \\
\hline Publications & $1,349,942$ & - & $1,349,942$ & - & - & $1,349,942$ \\
\hline TOTAL PROGRAM SERVICES & $67,530,503$ & $3,155,775$ & $70,686,278$ & - & - & $70,686,278$ \\
\hline \multicolumn{7}{|l|}{ Supporting services } \\
\hline Management and general & $13,288,902$ & 387,197 & $13,676,099$ & - & - & $13,676,099$ \\
\hline Fundraising & 872,516 & - & 872,516 & - & - & 872,516 \\
\hline TOTAL SUPPORTING SERVICES & $14,161,418$ & 387,197 & $14,548,615$ & - & - & $14,548,615$ \\
\hline TOTAL OPERATING EXPENSES & $81,691,921$ & $3,542,972$ & $85,234,893$ & - & - & $85,234,893$ \\
\hline $\begin{array}{l}\text { (Deficiency) excess of operating } \\
\text { revenue over operating expenses }\end{array}$ & $(4,987,259)$ & $3,351,587$ & $(1,635,672)$ & 914,238 & - & $(721,434)$ \\
\hline \multicolumn{7}{|l|}{ Other changes in net assets } \\
\hline $\begin{array}{l}\text { Gain on lease obligation and other, } \\
\text { net }\end{array}$ & 172 & - & 172 & - & - & 172 \\
\hline $\begin{array}{l}\text { Pension and other postretirement } \\
\text { charges other than net periodic } \\
\text { benefit cost }\end{array}$ & 172,264 & - & 172,264 & - & - & 172,264 \\
\hline Transfer from endowments & $4,205,548$ & $8 \quad(3,110,052)$ & $1,095,496$ & $(1,095,496)$ & - & - \\
\hline DECREASE IN NET ASSETS & $(609,275)$ & 241,535 & $(367,740)$ & $(181,258)$ & - & $(548,998)$ \\
\hline $\begin{array}{l}\text { NET ASSETS AT BEGINNING } \\
\text { OF YEAR }\end{array}$ & $2,285,463$ & $71,823,347$ & $74,108,810$ & $11,025,934$ & $5,485,776$ & $90,620,520$ \\
\hline NET ASSETS AT END OF YEAR & $\$ 1,676,188$ & $72,064,882$ & 73,741,070 & $10,844,676$ & $5,485,776$ & $90,071,522$ \\
\hline
\end{tabular}


BALANCE SHEET (For the year ended December 31, 2016)

TOTAL

\section{ASSETS}

Cash and cash equivalents

$\$ 8,903,899$

Grants and contributions receivable, net

U.S. government agencies

$9,420,796$

Other

$5,700,175$

Other receivables

698,549

Prepaid expenses and other assets

$1,801,992$

Postretirement medical benefits trust

$4,799,958$

Investments

$98,729,206$

Fixed assets, net

$12,765,919$

TOTAL ASSETS

$142,820,494$

\section{LIABILITIES AND NET ASSETS}

Liabilities

Accounts payable, accrued expenses, and other liabilities

$\$ 5,115,181$

Awards, contracts, and fellowships payable

$5,742,584$

Program advances

$13,784,376$

Deferred revenue

$4,243,935$

Loans payable

$8,214,286$

Deferred rent credit

$5,384,100$

Accrued lease obligation

142,457

Postretirement medical benefits payable

$10,121,754$

TOTAL LIABILITIES

Net assets

Unrestricted

General undesignated

$1,676,188$

The John D. Rockefeller 3rd Memorial Fund and others

$72,064,882$

SUBTOTAL UNRESTRICTED

$73,741,070$

Restricted

Temporarily restricted

Permanently restricted

A copy of the audited financial statements, prepared in accordance with U.S. generally accepted accounting principles, is available upon request from Population Council,

One Dag Hammarskjold Plaza, New York, New York 10017, and can be accessed online at popcouncil.org. 


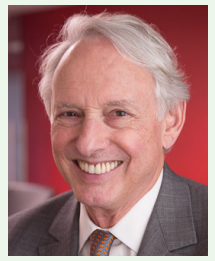

The 2016 Mark Walker Fellowship honors the extraordinary service of our outgoing Chairman of the Board of Trustees. Throughout his 13 years of service on the Board, Mark Walker provided passionate leadership and support to the Council as it deepened its commitment to working on behalf of adolescent girls.

The one-year fellowship supports Council scientists in generating, synthesizing, and translating rigorous research on the risks and realities of girls' lives, and determining which interventions have a proven impact on improving girls' lives and how to best direct investments to have meaningful effect. The research draws on more than 20 years of evidence gathered by the Council and partners and housed within the Council's new Girl Innovation, Research, and Learning (GIRL) Center.

\section{SOURCES OF SUPPORT}

The Population Council is grateful to each of our donors, whose generosity makes our work possible. Funding for the Population Council's work was provided by government agencies, multilateral organizations, foundations, corporations, and individuals. We value our longstanding relationships with many of these donors and welcome the support from new ones. Their commitment allows the Council to deliver solutions to critical health and development challenges and improve lives.

\section{GOVERNMENTS AND GOVERNMENTAL AGENCIES}

Government of Ireland -Irish Aid

Government of the

Netherlands

- Embassy of the Kingdom of the Netherlands

Government of Norway

- Norwegian Agency for Development Cooperation (NORAD)

Government of Sweden

- Swedish International Development Cooperation Agency (SIDA)

Government of the United

Kingdom

- Department for International Development (DFID)

Government of the United States

$$
\begin{aligned}
& \text { - Agency for } \\
& \text { International } \\
& \text { Development (USAID) } \\
& \text { - Centers for Disease } \\
& \text { Control and } \\
& \text { Prevention (CDC) } \\
& \text { - National Institutes of } \\
& \text { Health (NIH) }
\end{aligned}
$$

MULTILATERAL
ORGANIZATIONS

United Nations Children's Fund (UNICEF)

United Nations Entity for Gender Equality and the Empowerment of Women (UN Women)

United Nations Foundation

United Nations Population Fund (UNFPA)

World Bank Group

World Health

Organization (WHO)

\section{FOUNDATIONS/ CORPORATIONS/ OTHER \\ NONGOVERNMENTAL ORGANIZATIONS}

Anonymous (2)

Abt Associates Inc.

AmazonSmile Foundation

American Jewish World Service (AJWS)

The American University in Cairo

Atlantic Philanthropic Services Co.

AT \& T
Avenir Health

The Barr Foundation

The Batonga Foundation

Bayer HealthCare

BIZIT Group

BP Foundation, Inc.

BSC Group Services, LLC

Cleary Gottlieb Steen \& Hamilton LLP

Columbia University Medical Center

Community Media Trust (CMT)

Comunidades de la Tierra

Crown Agents Limited

Dell Employee

Engagement Fund

Deutsche Gesellschaft für Internationale

Zusammenarbeit GmbH

DiRaimondo \& Schroeder LLP

Elton John AIDS Foundation

EngenderHealth

Evofem Biosciences, Inc.

$\mathrm{FHI} 360$

Fidelity Investments Charitable Gift Fund*

The Ford Foundation
Forschungsinstitut zur Zukunft der Arbeit $\mathrm{GmbH}$

The Bill \& Melinda Gates Foundation

Girl Effect

Global Health Corps (GHC)

Goldman Sachs \& Co. Guttmacher Institute Health Decisions H\&M Hennes \& Mauritz

The William and Flora Hewlett Foundation

Fred Hutchinson Cancer Research Center

Inter-American Development Bank (IDB)

International HIV/AIDS Alliance

International Initiative for Impact Evaluation (3ie)

International Labour Office

International Planned Parenthood Federation (IPPF) 

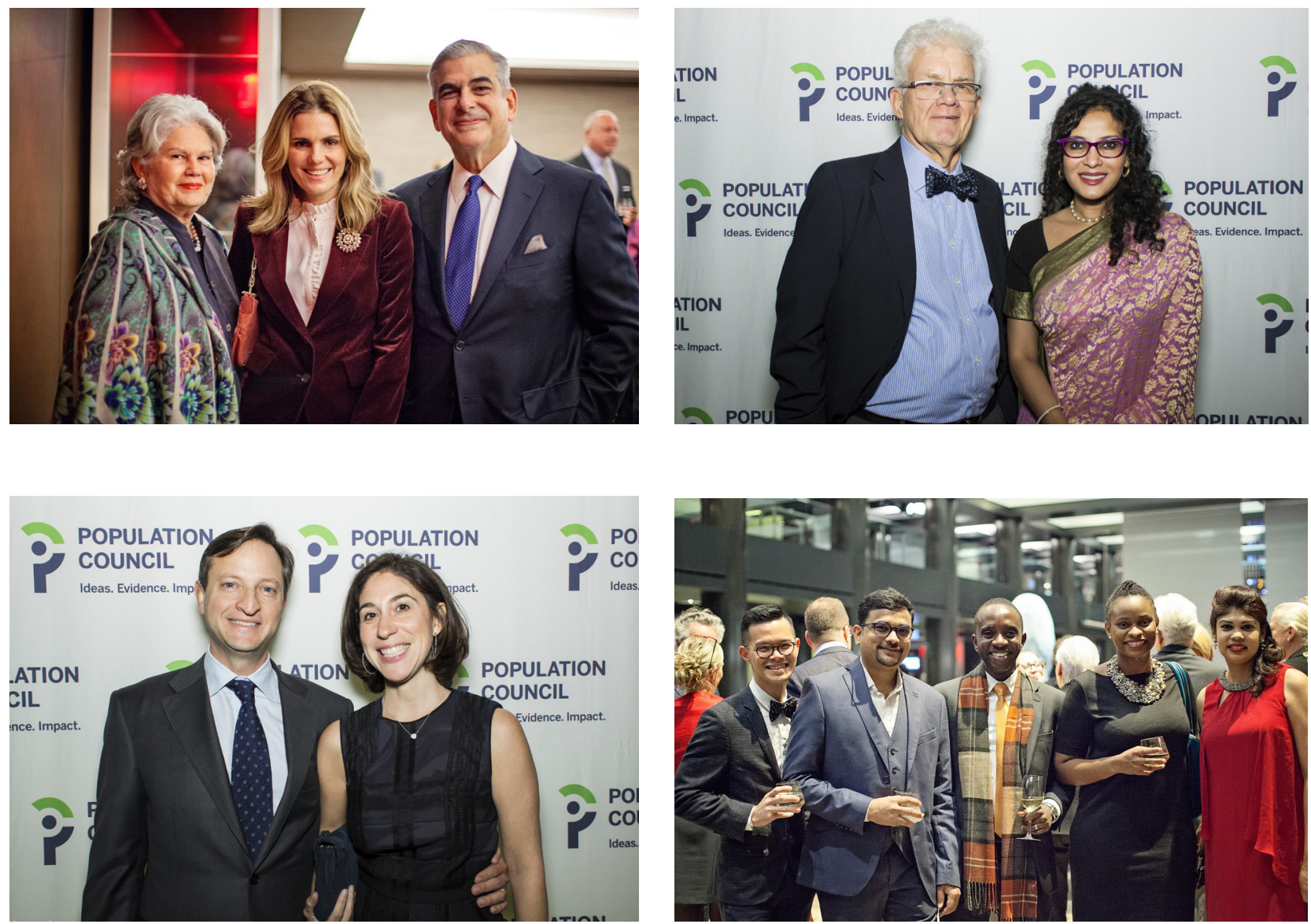

Supporters and friends join the Population Council at the Ideas with Impact Awards Gala in New York City. (Clockwise from top) Mary Ann Holguin, Elizabeth Zobel de Ayala, Jaime Zobel de Ayala;

Terry Walker, Nandana Sen; Mark Saiontz, Stacey Saiontz;

Thoai Ngo, Niranjan Saggurti, Chernor Bah, Aissatou Diallo, Johana Tima. 
Henry M. Jackson

Foundation for the

Advancement of Military

Medicine

JSI Research \& Training Institute

The W. K. Kellogg

Foundation

KPMG LLP

Los Angeles Biomedical Research Institute at Harbor-UCLA

John D. and Catherine T. MacArthur Foundation

Magee-Women's Research Institute and Foundation (MWRIF)

Marie Stopes International (MSI)

Merck Sharp \& Dohme Corp.

Microsoft Matching Gifts Program

Millstein \& Co.

Millstream Fund Inc.*

National Agency for the Control of AIDS (NACA)

Nike Foundation

NoVo Foundation

The Oak Foundation

Options Consultancy Services Limited

The David \& Lucile Packard Foundation

PayPal Giving

Program for Appropriate Technology in Health (PATH)

Project Concern International

ProQuest

Public Health Foundation of India (PHFI)

Research Foundation of the City University of New York

Rockefeller Philanthropy Advisors (RPA)

Rowman \& Littlefield Publishing Group

Rozan

Rutgers Pakistan

SageView Advisory Group

Save the Children
Society for Family Health

(SFH) Nigeria

SRI International

The Summit Foundation

Tinker Foundation

TPG Architecture, LLP

Truist

United Way of Rhode Island

University of Connecticut

Health Center

University of Pittsburgh

University Research Co.,

LLC (URC)

Wits Reproductive Health

\& HIV Institute

Yale University

Zambia Health Education

and Communications

Trust (ZHECT)

ZanaAfrica Group

INDIVIDUAL

DONORS AND

FAMILY FOUNDATIONS

JOHN D. ROCKEFELLER

3RD VISIONARIES

Hope Aldrich*

The Avis and Clifford

Barrus Medical

Foundation

Darcy Bradbury and

Eric Seiler*

Peter Brandt and Laura

Burwick*

Julia Bunting and Barrie Thring

C.S. Craig Family

Foundation*

Jerry and Diane

Cunningham*

The Edlow Family*

Kyung J. Kim*

Kirby Foundation, F.M., Inc.

The Minneapolis

Foundation

Nirvana Manana Institute

Valerie Tarico and Brian Arbogast*

Sukey Wagner*

Douglas R. Wilson

Elizabeth and Jaime

Zobel de Ayala*
PRESIDENT'S

LAUREATES

Joel W. Ager*

Tammy Allen and Daniel Gropper*

BeP Earthwise

Foundation

Natalia Bulgari and

Todd Hollander

Barbara B. Ebert

Alva Greenberg*

Victor Halberstadt*

Head Family Charitable

Foundation

Terry Peigh and Cindy

G. Fluxgold*

Gloria Sage

Xixi and Jonathan Shakes

Mark A. and Tania Walker*

COUNCIL

CHAMPIONS

D.E. and Angelica

Baird*

Ann Blanc

Carl Marks \& Co./

Andrew M. and Carol

L. Boas*

Willard B. Brown*

George P. and

Chingching Cernada

Colliers International

NY LLC

John and Lilly

Combias*

George and Jane

Creasy

Peter Curran

EcoTrust

Independent Charities of America/Health \& Medical Research

John and Janet Irwin

Carolyn Makinson and Terry Walker

The Katherine

McKinney Memorial Fund

Bethany and Robert B. Millard

Wanda J. Olson

Robert Porter

Nicolas Rohatyn and Jeanne Greenberg Rohatyn
Marc L. and Stacey

Saiontz

Leslie Samuels and Augusta Gross

Brian Short

Cherida Collins Smith

Sun Trust Foundation

COUNCIL

INNOVATORS

Anonymous (7)

Charles C. Abele*

David Abrams

Donald J. and Dena C. Abrams*

Diane Adams

Mar Aguilar

Alok and Nina Ahuja

Jeanne Akers

Shirley Alexander*

Timothy S. and Anne M. Allen

Peter O. Anderson

Linda Andes-Georges and Jean-Pierre Georges*

Sandra P. and Lawrence Arnold*

Astor Travel/Tzell Travel and Marie Mazzei and Donna Laurino

Christopher and Wanyong Austin

Michael Baird

Virginia H. Baker*

Nancy L. Balch*

Margaret E. Bancroft

Dror Bar-Natan

Jonathan and Judith Baron*

David Bausch

Kathi and Omar Bayne

Penelope N. Beasley

Katrina H. Becker*

Janice Beglau-Taylor

The Benevity

Community Impact

Fund

John Bermingham*

Ann Biddlecom

Benjamin Bilbao

William G. and Marie L. Blakney*

Thomas Blum

Ann Marie Bonardi and Salvatore Marras 
John and Zenaida

Bongaarts*

Jane K. Boorstein*

Joan N. and Barry

Boothe

Sylvia Boris*

Douglas H. Borsom*

David N. and Harriet B. Borton*

John W. and Claire Bossung*

Neil Botwinoff

Anita and Barney Brannen*

Deborah G. and Michael G. Branton *

Germán A. Bravo-Casas

Bridgewood Fieldwater Foundation

Steve and Sandy Brooks

Christopher N. Brown*

Trudy B. Brown*

Michael D. Butler*

Deborah R. Cable

Ann J. Cahill*

Cathy Cai

Caithness Foundation, Inc.*

Elaine A. Calos

Peter F. Cameron

Frieda R. Caplan

Emily Carmany*

William W. Chadwick, Jr.*

Richard and Laura Chasin

DeeMana Christoff

Barbara Cipolla*

Michele M. Clancy

Emily Clark-Youngblood Jeanne Clelland

J. W. Cliett*

William W. Cobbs, Jr.

Edward M. Cohen*

Theodore Cohn and Alice Ginott

Frances Combs

Laurie and Michael Constantino*

Harold and Cynthia Cook

Jean L. Cooper

David E. Cowles

Barbara B. Crane

Matthew Crane
Christopher S. and

Karen H. Cronan

Roberto Cuca*

Arthur J. Curtze

Larence E. and Eileen

K. Cutler

Louis Dana*

Matthew D. and Nancy

Davis*

Elizabeth B. Day

Charles H. Debrovner*

Maria Jimena Del

Aguila Lacoste

Paul Demeny and

Marianna Boga*

Mary $H$. Dodge

Stanley F. and Elizabeth

G. Dole*

Carey W. and Judith 0.

Donaldson

Peter J. Donaldson*

Kathryn Dorman

Douglas W. Doucette

Greg Edblom*

Ellenoff Grossman \&

Schole LLP/Amanda

M. Fugazy

Zora Ann Ellis

Wafaa El-Sadr*

Truls and Sarah

Engebretsen

Jan Epstein*

Andrea Eschen*

Nevill Eschen*

Donna J. Evans

H. K. and Nancy W. Faulkner*

Glen M. Feighery*

Zong-ming Feng*

Rosalind E. Finn

Bruce and Daria

Fireman

Gerald and Ruth

Fischbach

Douglas T. Fischer and

Robert Haines*

Bjorn Flesaker and

Laura Quigg

Matthew J. Fortune

Edward D. and Ramona

C. Foulke

James Fox

Anne E. Fry*

Janet R. Gabor

Charles W. and Jane L. Gardiner*
Sheryl P. Gardner*

Lydia Garvey*

Sigmund and Carol Gast

Mary Geissman*

Gwen P. Gentile

Laura Ghini

Leslie Giering

Mark M. Giese

Duff Gillespie

Anna Glasier*

Eitan Glinert

Carey Goldberg

Rachel E. Goldberg and

Zachary T. Nelson

Elaine R. Goldman

Joe and Courtney

Goldsmith

Marc and Carol Gordon

Gorlitz Foundation, Ltd.

Sallie T. Gouverneur

William M. Grady and

Karen D. Tsuchiya

Susan W. Granger

Catherine Grant*

Anita Grath

Diane Greenberg

Mary J. Greer*

David Grill*

Lucy Grimes

Molly A. Grodin

Augusta Gross and

Leslie Samuels

Sheila Gudiswitz

Nancy J. Gunther*

Angel Gurria

Marjorie Gustafson*

Anke and Peter

Haberland

Michele Haberland and

Thaddeus Tracy

Nicole Haberland

Scott Haese*

Joseph V. Hahn

Robert Metcalf Hall, Jr.

Kelly Hallman

Karen Hardee

Julie Harkins

Katharine Harkins

Aljean and Richard S.

Harmetz

Guy Harris*

Taylor Hartman

William G. and Caroline

K. Hatton
Amy Hause

Dirk F. and Dixie R. Havlak

Thomas C. Hayes

Mark A. and Jane D. Heald

Stephen F. Heartwell

Donald F. Heisel

Mary W. Heller*

David Hendin

James F. Herndon

Willard J. and Annette

B. Hertz*

Judith Herzfeld*

Susan J. Hessel

The William W. Hildreth Fund

Alexander Hill

Jessica Hill

Edward S. Hochman*

Frederick W. Hollmann

William Y. and Esther

I. Hou

Holiday S. and Philip A. Houck*

The Richard R. Howe Foundation

Chi Huang

Albert and Cherry Huen

Gary H. and Janice E. Hunsinger

Catherine M. Hunt

William P. Huxley

Frederick V. Iffert*

Henry and Pauline Imus

Robert Ingram and Lynda Eckard*

Anna Irwin

Catherine Jackson

Walter G. and Susan B. Jacobs *

Anrudh and Usha Jain

Kenneth and Priscilla Jamieson

Monwhea Jeng

Mark S. Jenne

Richard S. Johnson and May J. Reed

Theresa M. and Bruce D. Johnson Foundation

Elise F. Jones*

Robert Joyce

Nancy Juette

Carmen and Karl A. Jungbluth* 
JustGive.org

J. E. Juterbock*

Jonathan and Ute Kagan

Martin Kahn

Kaiser Foundation

Health Plan of

the Northwest

Community*

James A. Kaplan

Marion S. Kaplan

Michael B. Keary

Deborah L. and Richard A. Keefe

Steven Keleti

John E. Kester

Charles W. Kettering

Paul M. Killough*

Brian and Lisa King*

Henry L. and Margaret

G. King*

A. Larkin Kirkman

Charles D. and Jane P. Klein*

Paul Klein

John Klimas

Margaret A. Knoll*

Sandra M. and

Theodore R. Koerner II

John Komendowski

Elliott and Sharon P. Krefetz*

Wayne V. Krill*

George Krumme and Aldean Newcomb* Janet Kuepper Joel Kurtzberg

Arthur and Eva Landy

Andrew Larner

Brian L. Larson*

Denise Laughman

Ingrid Laursen

Robert M. and Ruth C. Law*

Charles E. and Patricia

G. H. Lawrence

Fred and Juanita Leonard*

Jack G. Levine and Jeanette W. Melley*

Lloyd S. Levine

Susan Levine

Jason Lewin

Katherine Lewis

Jason A. and Linda E. Lillegraven*
Amy Little

Daniel LoCascio*

Martin and Rhoda Sue

Lonow*

Beau Lynn-Miller

John and Barbara

Lynskey

Walter and Ruth

MacGinitie

Maryann Macias

Landis MacKellar

Doug MacMillan

David and Jennifer

Madden

Douglas and Karen Madigan

Erik MaehImann

Lisa Maldonado

Roger and Isabel

Marchese*

Lewis Martinez*

Joel W. and Patricia A.

Marx*

Maryland Charity

Campaign

Anna C. Mastroianni

and Gregory M. Shaw

Deborah L. Maxwell

Peter J. Mayer*

Cheikh Mbacké*

Elizabeth J.

McCormack*

Hugh McGaughy

Geoffrey McNicoll

Joan N. and Jacob

Meerman*

Michelle and Rolf J.

Mehlhorn

Surinder K. Mehta

Ruth and Irwin

Merkatz*

Lauren Meserve*

John L. and Irene W.

Meulemans

Stanley and Patricia

Mierzwa

Peter Miller

John Mirsky

James Mitchell

Samarendranath and

Rekha Mitra

Thomas J. and

Elizabeth V. Mooney

Katharine B. Morgan

Courtney Morris

Gretchen Morris
Patricia Morris

Lloyd N. and Mary P. Morrisett*

Susan K. and

Christopher Moss*

Charles Stewart Mott

Foundation

Scott B. Mouw

Marita K. Murman

William Myers

Ann and William T. Naftel*

Jeremy Naftel and

Rachel Beck*

Charles B. Nam*

Clark Natwick

Barbara and Patrick

K. Nee

LeRoy E. and Anita L. Nelson*

Network For Good

Thoai Ngo

Enmei Niu*

Wendell A. Norvell

The Roger and Joyce Nussbaum

Foundation*

William E. O'Connor*

Odunola Ojewumi

Megan O'Keefe

Debra Olchick

Lynn F. Olson*

David Osterman

Ostgrodd Foundation

Kelli and Stephen W. Pacicco

Ruth Hyde Paine*

Robert H. and Jessie Palmer*

Leonard M. Passano

Jeffrey S. Passel*

Michelle Patterson*

Jane S. Pattie*

Daniel K. and Susan A.

Paulien*

Tomas J. Pavel*

Anne R. Pebley and

Barry M. Wolf*

Jessica G. Perri

Scott and Linda Perry*

Eugene W. Peterson

Clyde C. Phillips, III*

Linda Pierce*

Play for Your Cause

Philip G. Pollock and

Carolyn Sue Beavert*
David Porteous and

Vicky Smith

Ann Pugh*

Joelle Raichle*

Kanuru S. Rao*

John P. and Brenda L. Raphael*

Habib Rathle*

Apurba K. and Krishna Ray

Bayard D. Rea

Phillip F. and Andrea

Reid*

Warren R. and Nancy J. Reinecke

Ralph and Danute Reisner

Rhodes Family Fund

David S. Rice*

Marilyn and Juan Richardson*

Thomas L. Richie and Diane Pascal

George M. and Frances R. Ricker

Amy Riddle

Eleanor Rieffel

Julie Robichaud*

Sara Robinson

Mordecai Rochlin

Charles P. Rockefeller

David Rockefeller*

Justin A. Rockefeller*

Bruce Rockwell

Beth Roemer

Charles S. and Evelyn S. Rose*

Marilyn Rosenblatt

Lance and Sura

Rosenthal

Ira Rosenwaike*

Penelope and Cornelius Rosse*

Gregory T. Rotter*

Edward and Sharon Rubin

Robert Ruether

Anita and Lorenzo Sadun

James E. Sailer and Cass Conrad*

Craig Savel and Marion Stein

Karen P. Schaefer*

Tanya SchartonKersten 
Nancy J. Schieffelin*

Frederick H. Schmidt*

Steven Schmitt*

Brian Schneidewind

Sarah Schroeder

Adine Schuman-Pusey

Joel Schwartz

Connie Schwarzkopf

Susan Scoppetta

Jutta R. Scott*

Harriet Segal

Akash Sehgal

William D. Selles

Marianne E. Selph*

Cynthia L. and Michael

D. Sevilla*

Eric Shaqfeh

G. Edward and Joyce Shissler*

Daniel Silver

James Simonds

H. K. Sinclair*

Peter Sinclaire*

Frank W. Sinden

Marion L. Siu

Walter and Susan Slowinski

M. K. Smith*

Michael C. T. and Linda

L. Smith*

Nancy V. Smith*

Georgeanne Spates*

Theodore and Tracy

Spencer

Jeffrey Spieler

Abigail Stahlman

Sylvia C. and Donald F.

Stanat

Karen Steel

Jacob and Hilde

Stempel*

Sally Stephens

Sue Stewart*

Kathryn Stokes and

David Esseks

Bertram and Lynne Strieb*

Kathryn Sugerman

Ya-Ping Sui

John K. and Elizabeth

A. Sullivan*

Te-Hsiung Sun*

Ali Sussman
Robert and April

Sussman

Alan S. and Danna

Taylor*

Fred R. Taylor and

Jeanne M. Twigg-

Taylor

Miriam Temin

Richard G. Terry

Timothy Thomas

Brandt Thompson and Anna Nordberg Thompson

Johana Tima

Harriet B. Todd*

Michael J. and Marina Todd

Arlene Torres

William J. and Faith M. Towle*

John and Judy

Townsend*

William Tretbar

Namrata Tripathi

Amy Ong Tsui

Ramachandra

Tummala

Vicki Turano

George Vacek*

Pablo Vallecilla

Kathy and David G. Van

Dame*

Margaret Vaughan

Patricia C. Vaughan

Maria Vinardell

Katherine Voskian

Stephen and Yvonne

Vosti

Joel Walker

Mary and Eric Walker

Tim Walter*

Jordan and Nicole

Warshaw*

Valerie Wayne

Diana K. Weatherby

Frank C. Wedl*

Thomas E. and Julia E.

Weeks*

Peter A. Weida*

Jed Weissberg and

Shelley Roth*

Barbara F. Wells*

Michael White
Wichita Falls Area

Community

Foundation

Edward and Linda

Williams*

Robert V. and Maralys

K. Wills

Alex and Marguerite

Wilson

Paul Winder

Doug Wingo and Tim

Legg

Beverly Winikoff

M. K. Winslow

Ellen Wisdom and

Robert L. Griswold

Oliver and Hellen M.

Wolcott*

Linda W. Wolf

Warren Wong

Gooloo S. and Gene

Wunderlich*

Barbara Yanni*

Alice M. Young*

YourCause

Boniface Zaino*

Jerrold H. and Carol B.

Zar*

H. N. Zimmerman*

David Zuckerman

Suzanne C. and Paul L. Zuzelo*

\footnotetext{
* Consecutive Annual Fund

Donor for at least five years
} 


\section{Darcy Bradbury \\ Chair \\ Managing Director \\ The D.E. Shaw Group \\ New York, New York}

\section{Zulfiqar A. Bhutta}

Robert Harding Chair in Global

Child Health \& Policy and

Founding Director of the Centre

for Excellence in Women and

Child Health

Hospital for Sick Children and

The Aga Khan University

Toronto, Canada and Karachi,

\section{Pakistan}

\section{Peter Brandt}

Stamford, Connecticut

\section{Julia Bunting}

President

Population Council

New York, New York

\section{Wafaa El-Sadr}

Professor of Clinical Medicine and Epidemiology

Mailman School of Public Health

Columbia University

New York, New York

\section{Anna Glasier}

Honorary Professor

Department of Obstetrics and Gynecology

University of Edinburgh

Edinburgh, United Kingdom

\section{Victor Halberstadt}

Professor of Public Sector Economics

University of Leiden

Netherlands

\section{Jonathan Kagan}

Managing Principal

Corporate Partners

New York, New York

\section{Anna Mastroianni}

Professor of Law

University of Washington School of Law

Seattle, Washington

\section{Lauren A. Meserve}

Chief Investment Officer

Metropolitan Museum of Art

New York, New York

\section{Wanda Olson}

Senior Counsel

Cleary Gottlieb Steen \&

Hamilton LLP

New York, New York

\section{Terry Peigh}

Senior Vice President,

Managing Director

Interpublic Group of Companies

New York, New York

\section{K. Sujatha Rao}

Hyderabad, India

\section{Marc L. Saiontz}

Managing Director

American Securities Capital

Partners, LLC

New York, New York

\section{Theo Spencer}

Senior Advocate

Natural Resources Defense

Council

New York, New York

Jeffrey M. Spieler

Bethesda, Maryland

\section{Amy Ong Tsui}

Professor and Senior Scholar

Bill \& Melinda Gates Institute for Population and

Reproductive Health

Johns Hopkins Bloomberg School of Public Health

Baltimore, Maryland

\section{Kaye Wellings}

Professor of Sexual and Reproductive Health

London School of Hygiene \&

Tropical Medicine

London, United Kingdom

\section{Elizabeth Eder Zobel de Ayala}

Chairman

Teach for the Philippines

Makati City, Philippines
Julia Bunting

President

Ann K. Blanc

Vice President

Social and Behavioral Science Research

\section{John Bongaarts}

Vice President and

Distinguished Scholar

\section{Erin Kiernon*}

Chief of Staff to the President and Head of External Relations

\section{James E. Sailer}

Vice President and Executive Director

Center for Biomedical Research

Patricia C. Vaughan

General Counsel and Secretary

Eric Walker

Chief Financial Officer

* Until June 2017.

\section{Cheikh Mbacké}

Independent Consultant

Dakar, Senegal 


\section{UNITED STATES}

\section{Headquarters}

Population Council

One Dag Hammarskjold Plaza

New York, NY 10017 USA

Tel +1212 3390500

Fax +12127556052

E-mail pubinfo@popcouncil.org

\section{Center for Biomedical Research}

Population Council

1230 York Avenue

New York, NY 10065 USA

Tel +1 2123278731

Fax +12123277678

E-mail biomed@popcouncil.org

\section{Washington, DC}

Population Council

4301 Connecticut Avenue, NW

Suite 280

Washington, DC 20008 USA

Tel +12022379400

Fax +12022378410

E-mail popcouncil@popcouncil.org

\section{INTERNATIONAL}

\section{Bangladesh}

Population Council

House \# 12, Road \#25/30

Gulshan-1, Dhaka, Bangladesh 1212

Tel +880-2-984-2276

Fax +880-2-984-3127

E-mail info.bangladesh@popcouncil.org

\section{Burkina Faso}

Population Council

Secteur 15 Ouaga 2000, Zone B 1296

Avenue Ousmane Sembene

Porte N 1244/1246

Ouagadougou, Burkina Faso

01 BP 6250

Tel +226-25-37-52-19

Fax +226-50-31-12-46

E-mail info.burkinafaso@popcouncil.org

\section{Cambodia}

Population Council

\# 12 Eo. St. 41. Sangkat Tonle Bassac

Phnom Penh, Cambodia

Tel: +855-10-330-184

E-mailinfo.cambodia@popcouncil.org

\section{Egypt}

Population Council

59 Misr-Helwan Agricultural Road

Maadi, PO Box 168

Cairo, Egypt 11431

Tel +20-2-2525-5968

Fax +20-2-2525-5962

E-mail info.egypt@popcouncil.org

\section{Ethiopia}

Population Council

Heritage Plaza, 4th Floor

Bole Medhaneialem Road

Addis Ababa, Ethiopia

Tel +251-116-631-712

Fax +251-116-631-722

E-mail info.ethiopia@popcouncil.org

\section{Ghana}

Population Council

14B Ridge Road

Roman Ridge

Accra, Ghana

Tel +233-30-2-780711

Fax +233-30-2-780713

E-mail info.ghana@popcouncil.org

\section{Guatemala}

Population Council

19 Avenida 0-35

Zona 15, Vista Hermosa 2

Guatemala City, Guatemala 01015

Main tel +502-2369-0292

Alternate tel $+502-5293-0030$

Alternate tel +502-2369-2760

Fax +502-2369-6919

E-mail info.guatemala@popcouncil.org

\section{India}

Population Council

Zone 5A, Ground Floor

India Habitat Centre, Lodi Road

New Delhi, India 110003

Tel +91-11-2-464-2901

Fax +91-11-2-464-2903

E-mail info.india@popcouncil.org

\section{Kenya}

Population Council

Avenue 5

3rd Floor, Rose Avenue

Nairobi, Kenya

Tel +254-20-271-3480

Fax +254-20-271-3479

E-mail info.nairobi@popcouncil.org

\section{Mexico}

Population Council

Insurgentes Sur \#2453

Torre Murano Piso 9 Local 903

Colonia Tizapán, Delagación

Álvaro Obregón

México D.F. México 01090

$\mathrm{Tel}+52-55-5999-8645$

Fax +52-55-5999-8631

E-mailinfo.mexico@popcouncil.org

\section{Nigeria}

Population Council

House 4, No. 16B, POW Mafemi

Crescent, Utako District

Abuja, Nigeria

Tel +234-806-778-7750

E-mail info.nigeria@popcouncil.org

\section{Pakistan}

Population Council

3rd Floor, National Telecommunication

Corporation (NTC) Regional

Headquarters (North)

Sector F-5/1

Islamabad, Pakistan

Tel +92-51-920-5566

Fax +92-51-282-1401

E-mail info.pakistan@popcouncil.org

\section{Senegal}

Population Council

Sacré Coeur 3 Pyrotechnie

85 Appartement 2ème Etage à Droite BP21027 Dakar Ponty, Dakar, Senegal

Tel +221-33-859-5300

$\mathrm{Fax}+221-33-824-1998$

E-mail info.senegal@popcouncil.org

\section{Zambia}

Population Council

Plot \#3670, No. 4 Mwaleshi Road

Olympia Park

Lusaka, Zambia 10101

Tel +260-211-295925

Fax +260-211-295925

E-mailinfo.zambia@popcouncil.org 
$p-1=0,1,2=02$

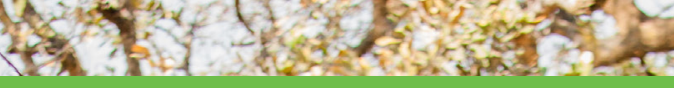

- 14 THE POPULATION COUNCIL IS ON THE RY FRONTLINES. IT GOES WHERE OTHER INSTITUTIONS AND POLICY GROUPS AREN'T DIS ABLE TO GO, AND IT UNDERSTANDS THE FACTS ON THE GROUND."

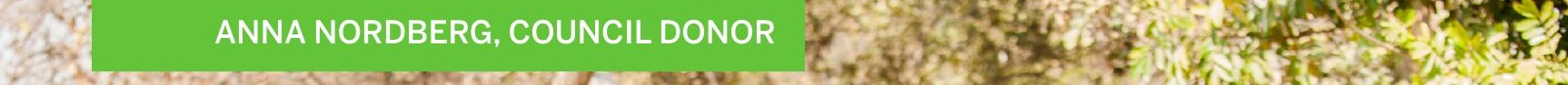

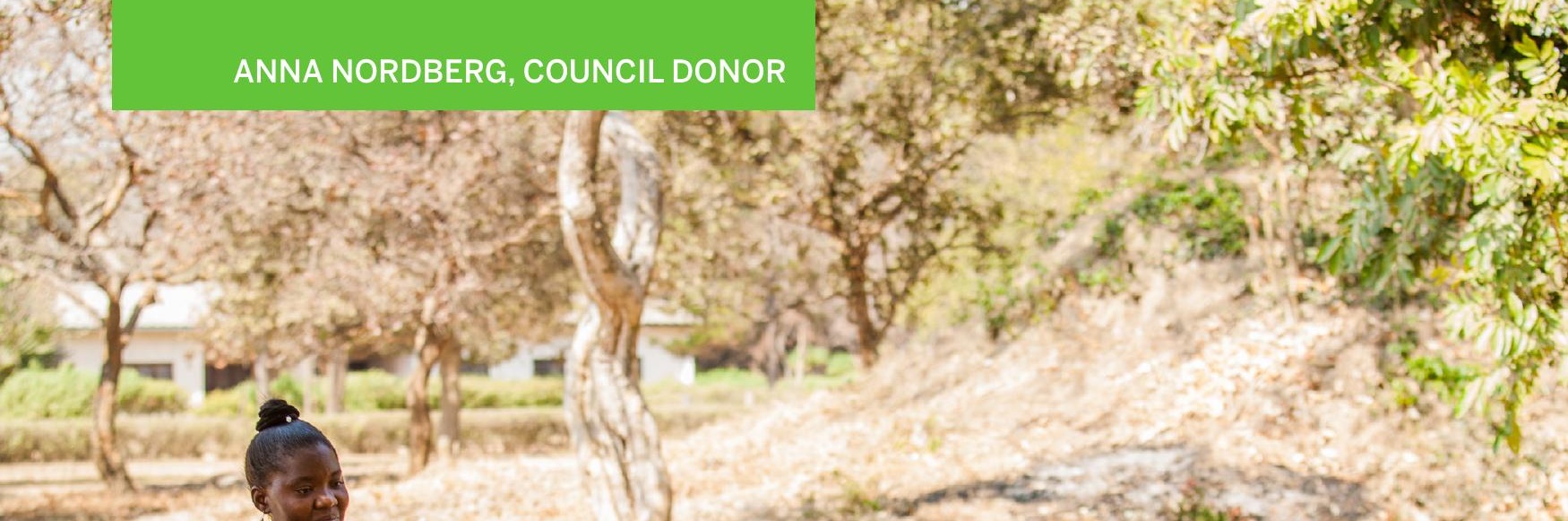

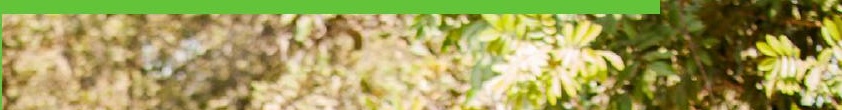
C 30 in $\cos x \log ^{2}$
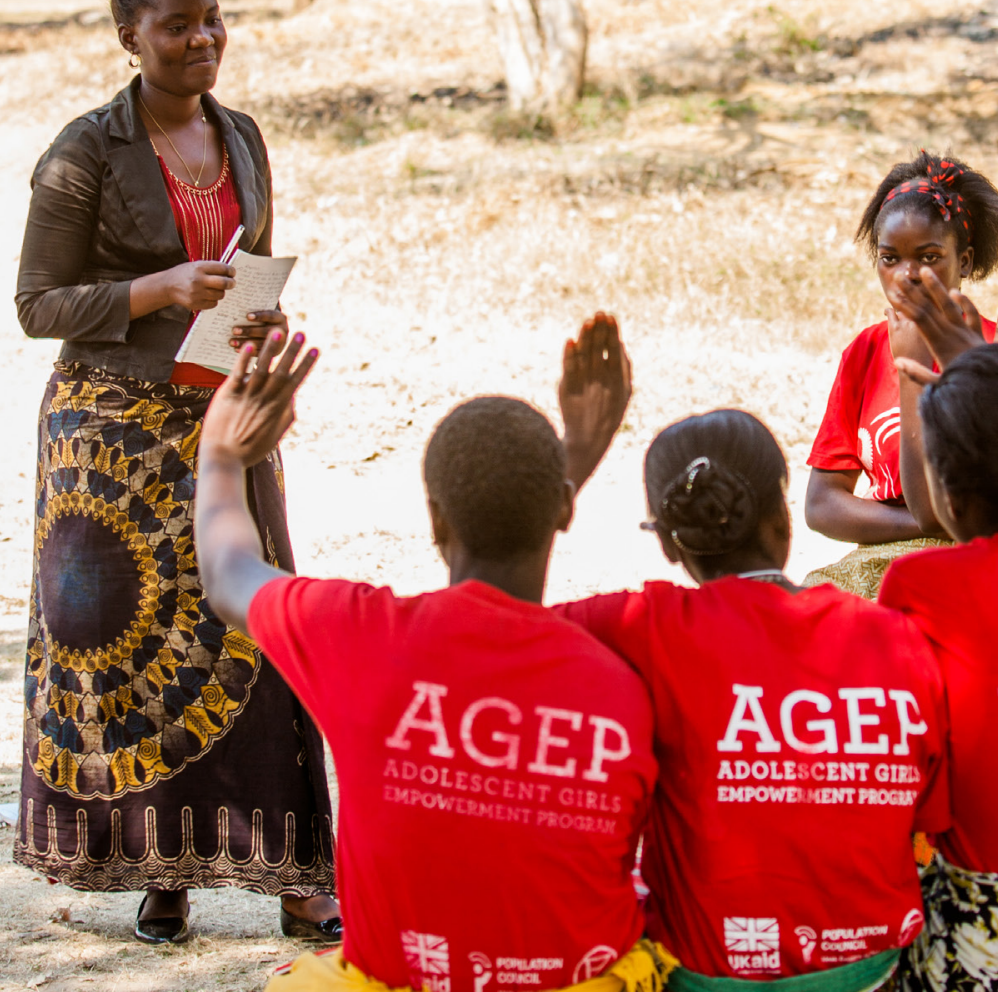

AGEP

AGEl

J ADOLESCENT C.

2.

-

(t)

are
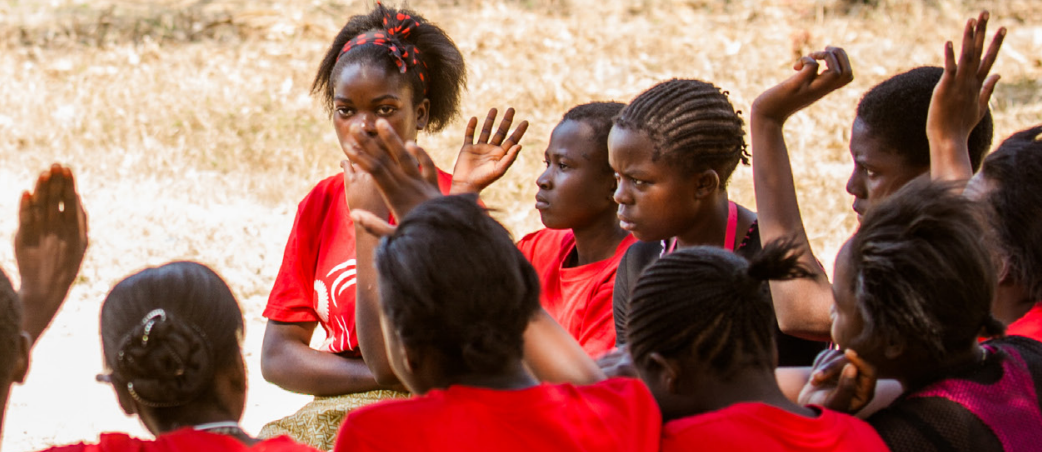

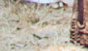




\section{P. Population}

The Population Council confronts critical health and development issues-from stopping the spread of HIV to improving reproductive health and ensuring that young people lead full and productive lives. Through biomedical, social science, and public health research in 50 countries, we work with our partners to deliver solutions that lead to more effective policies, programs, and technologies that improve lives around the world. Established in 1952 and headquartered in New York, the Council is a nongovernmental, nonprofit organization governed by an international board of trustees.

(c) 2017 The Population Council, Inc.

Library of Congress Catalog Number 78-617856 ISSN 0361-7858

Printed on recycled paper using vegetable-based inks. 